\title{
Notes on Contributors
}

James Baker is an Assistant Lecturer in the School of History at the University of Kent, Canterbury. He has recently completed a doctoral thesis entitled 'Isaac Cruikshank and the Notion of British Liberty: 1783-1811'. His current research focuses on the social, economic and environmental processes that underpinned the satirical print trade between 1750 and 1850 , the centrality of caricature, stereotyping and exaggeration to the functioning of European society and the representations of Jewish immigrants in Georgian graphic satire.

Farid Boudjellal is a French cartoonist who has been publishing comics since 1978. His first comic books were issued by Futuropolis in the 1980s: L'Oud ['The Lute'], Le Gourbi ['The Hovel'], Ramadân ['Ramadan'] and Les Soirées d'Abdulah: Ratonnade ['Abdulah's Evenings: Lynching an Arab']. He has published comics infused with fantasy (his trilogy of books on a djinn ['genie']) and humour (e.g., his Juif-Arabe ['Jew-Arab'] series). A number of his works have come out with Soleil, Tartamudo and elsewhere. Many of his books are again being published or reissued by Futuropolis - for example, his Petit Polio ['Little Polio'] series and Les Années Ventoline ['The Ventoline Years']. He is currently working on a new volume entitled Le Cousin harki ['The Harki Cousin']. His work has received many prizes, including at the Angoulême comics festival, and has been the object of media and scholarly interest in France and abroad.

Morgan Di Salvia, born in 1981, studied contemporary history at the University of Brussels (Université Libre de Bruxelles). His master's thesis was about the Belgian cinema industry. In the domain of comics he has fulfilled various functions: retailer, journalist and exhibition curator. In 2010, he collaborated on the catalogue Manières noires ['Dark Manners'], a transdisciplinary exhibition in the BAM (Musée des BeauxArts de Mons) and on the book Bande dessinée et illustration en Belgique: États des lieux et situation socio-économique du secteur ['Comics and Illustration in Belgium: An Overview of the Sector's Socio-Economic Situation'] (Brussels: SMartBe).

Anna Giaufret is Ricercatore in French Linguistics at the Faculty of Foreign Languages and Literatures of the University of Genoa. After a PhD in Francophone Literature she devoted herself to translation and linguistics, mainly working on the analysis of 
interactive political discourse in the media (radio and television) and terminology (law, astronomy and energy from renewable sources). She is also interested in French comics from a linguistic point of view. Recent work includes articles on French in legal texts, on the issue of linguistic norms for teachers of French, on cultural diversity and metaphor and on nominal forms of address in radio interviews. The last article appears in a collection edited by Catherine Kerbrat-Orecchioni (S'adresser à autrui: Les Formes nominales d'adresse en français ['Addressing Others: Nominal Forms of Address in French'] (Chambéry: Presses Universitaires de Savoie, 2010), 201-224). She has written on Québécois comics art for a special edition of Publif@rum published in 2011 and available at http://publifarum.farum.it/ezine_articles.php?art_id=184.

Pascal Lefevre teaches courses on visual media at two Flemish university colleges of art (Sint-Lukas Brussel and MAD-Faculty in Genk) and is an affiliated researcher at the University of Leuven, Belgium. Selected publications are Pour une lecture moderne de la bande dessinée ['For a Modern Reading of Comics'] (with Jan Baetens), The Comic Strip in the Nineteenth Century (co-edited with Charles Dierick), Bande dessinée et illustration en Belgique: États des lieux et situation socio-économique du secteur ['Comics and Illustration in Belgium: An Overview of the Sector's Socio-Economic Situation'] (with Morgan Di Salvia). He is a member of the international editorial board or consultative committee of various academic journals. Currently he is researching early visual narratives, transmedia narration and hybrid fact/fiction narratives.

Fabrice Leroy is Professor of French and Francophone Studies at the University of Louisiana at Lafayette, where he teaches French and Belgian contemporary literature and graphic novels. He is the editor of the scholarly journal Études Francophones (http:// languages.louisiana.edu/ef/index.html). Among other projects, he co-authored the literary anthology Littérature française, t. 2 (Wiley, 1997); edited (with Adelaide Russo) a thematic issue of the journal Études Francophones devoted to Belgian comics (2005); and published a critical edition of Bras Coupé et autres récits louisianais (2007) by nineteenth-century Louisiana novelist Louis-Armand Garreau. He has published several articles and book chapters on French-language comics and is currently writing a booklength essay on Pierre La Police's comics, with Livio Belloï.

Morvandiau (the pen-name of Luc Cotinat), illustrator, political cartoonist and above all comics artist, has been widely published by independent presses. In 2007 , his very wellreceived comic book D'Algérie ['About/From Algeria'] was brought out by Homecooking Books. In 2010, Morvandiau returned to his habitual comic tone, publishing Les Affaires reprennent ['Business/Scandals as Usual'] and Santa Riviera ['Holy Riviera'] with Les Requins Marteaux. He was also involved in 2010 in putting together a special supplement of Le Monde Diplomatique dedicated to politically committed comics art. Since 2001, as a founder member of the organisation Périscopages, he has been promoting artistically ambitious comic art through an annual convention in Rennes. 